\title{
Herbage yield in Signalgrass pastures as affected by grazing management
}

\author{
G.J. Braga $^{1 \#}$, J.N. Portela ${ }^{2}$, C.G.S. Pedreira ${ }^{2}$, V.B.O. Leite ${ }^{1}$ and E.A. Oliveira $^{1}$ \\ ${ }^{1}$ APTA/SAA, PRDTA Centro-Oeste, R. Sebastião Soares s/n Brotas SP Brazil \\ ${ }^{2}$ USP/ESALQ, Departamento de Zootecnia, Av. Pádua Dias, 11 Piracicaba SP Brazil
}

\begin{abstract}
Signalgrass is largely planted as cultivated pasture in Brazil, but no management targets have been identified. The objective of this study was to evaluate daily herbage accumulation rate (HAR) in Signalgrass pastures grazed at two intensity x two frequency treatments using steers. Target intensities corresponded to 5 and $10 \mathrm{~cm}$ post-graze sward height and frequencies were determined by pre-graze sward light interception (LI $=95$ or 100\%) by the canopy. The trial was carried out from January 2007 to April 2008 on an Entisol. Less frequently grazed pastures had higher HAR during the entire period (29 and $36 \mathrm{~kg} / \mathrm{ha}$ for 95 and 100\%LI, respectively). There was no intensity effect on HAR, except in the 2007 summer season (January to March) when pastures grazed to $10 \mathrm{~cm}$ had a higher HAR (59 kg/ha) than those grazed to $5 \mathrm{~cm}(45 \mathrm{~kg} / \mathrm{ha})$. Total leaf yield increased when regrowth was longer (7930 vs. $8729 \mathrm{~kg} / \mathrm{ha}$ for 95 and 100\%-LI, respectively), but stem and dead material yield increased as well (4877 vs. $7155 \mathrm{~kg} / \mathrm{ha}$ for 95 and 100\%-LI, respectively). The advantages of extending the rest period due to increased HAR was counterbalanced by the great influence of stem and dead material, decreasing pasture leafiness and likely forage nutritive value on the grazed stratum.
\end{abstract}

Keywords: Brachiaria decumbens, grazing intensity, grazing frequency, rotational stocking

\# Corresponding author. E-mail: gjbraga@apta.sp.gov.br

\section{Introduction}

Original to the African continent Signalgrass (Brachiaria decumbens Stapf. cv. Basilisk) is the most cultivated grass in Brazil since the 1970s, due to its high persistence and dry matter yield. Decreasing use of Signalgrass over the last 20 years has been associated with its susceptibility to spittlebug (Deois sp.), and this has made for increasing area cultivated to new, resistant grasses such as Brachiaria brizantha, but it is still a significant forage species used in tropical areas of the country. Introduced in the Brazilian territory in the 1950s, Signalgrass management is mainly empirical and precise management targets based on plant characteristics have not been proposed for optimal use in grazing systems.

Many recent studies in Brazil have proposed a new approach to grazing management based on sward light interception (Marcelino et al., 2006; Barbosa et al., 2007). Inspired by studies of Broughan (1957) and Korte et al. (1984), this approach proposes that forage accumulation rate is maximised when sward light interception approaches 95 - 100\%, the point beyond which leaf senescence increases significantly, accompanied by increasing forage loss due to excessive growth of stems, mainly in tropical grasses. The objective of this study was to evaluate daily herbage accumulation rate (HAR) in Signalgrass pastures under combinations among two defoliation intensities and two frequencies, making for four grazing treatments, with frequencies based on levels of sward light interception.

\section{Materials and Methods}

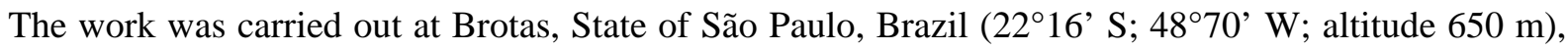
in a summer rainfall region with an annual average of $1350 \mathrm{~mm}$. The data were collected on a Signalgrass (Brachiaria decumbens Stapf. cv. Basilisk) pasture, growing on an Entisol, a typical soil of the Brazilian savannah (Cerrado). The experimental design was completely randomized consisting of four treatments (combination of two intensities and two frequencies of defoliation) with four replications. Intensity corresponded to 5 and $10 \mathrm{~cm}$ post-graze sward height and frequency was determined by pre-graze sward light interception ( $\mathrm{LI}=95$ or $100 \%$ ) in a factorial arrangement $2 \times 2$. The experimental period was from January 2007 to April 2008, and plot size was $8 \times 10 \mathrm{~m}\left(80 \mathrm{~m}^{2}\right)$. Defoliations were imposed by steers in a mob-grazing protocol, which consists of fast defoliations (1 - 2 h). Sward light interception was measured 
with a LAI-2000 canopy analyzer (Li-Cor, Lincoln, NE, USA). The LAI-2000 is comprised of a gauge unit and an articulated probe bar. The probe has a set of fisheye-type lenses that project a hemispherical image from the bottom to the top of the canopy through silica detectors. The gauge unit records the data and calculates leaf area index and LI. The procedure combines measurements of sky brightness, taken with the probe levelled above the canopy, with measurements taken at soil level. These measurements were always taken shortly after dawn or just before sunset (low solar elevation), because the equipment does not operate adequately under the predominance of direct solar radiation. In this experiment four readings were taken above the sward, combined with 20 readings at soil level, in each experimental paddock. Each reading taken above the canopy was followed by five readings at soil level. Herbage mass was estimated from clipping three quadrats $\left(0.30 \mathrm{~m}^{2}\right)$ per plot at pre-graze with 5 or $10 \mathrm{~cm}$ sward height from the soil, according to treatment. Plant-part components of the forage were separated in leaf, stem and senescent or dead material. Daily herbage accumulation rate (HAR) was calculated as pre-graze herbage mass divided by the days of the rest period. Data were analyzed using repeated-measures in time with the PROC MIXED of the SAS programme, and factors included in the analysis of variance were intensity, frequency, period of the year and its interactions. Least square means are compared using the Tukey test (5\%).

\section{Results and Discussion}

Despite of the proposed grazing intensity treatments, the mean sward stubble height was eight and 13 $\mathrm{cm}$ for the five and $10 \mathrm{~cm}$ treatments, respectively. These results suggest a considerable level of spatial heterogeneity in the plots, which influenced the grazing intensity targets. The mean pre-graze sward height that corresponded to the $95 \%$ and $100 \%$ LI treatments was 19 and $23 \mathrm{~cm}$, respectively. This association is an important feature about potential use of this management technique in grazing systems, due to its practicity and low cost of the sward height evaluations. Unexpectedly, the difference in pre-graze sward height between the two frequency treatments was very small. From January 2007 to April 2008 the average grazing interval corresponded to 51, 64, 41 and 57 days for the 5/95, 5/100, 10/95 and 10/100 intensity/frequency treatments, respectively. Despite the inclusion of 2007 "winter" evaluations (July to September), when the grazing interval was considerably increased, these data showed an effective and sensible distinction between management practices.

HAR was affected by period, frequency and by the period $\mathrm{x}$ intensity interaction $(\mathrm{P}<0.0001)$. There was no effect on HAR due to intensity, intensity $\mathrm{x}$ frequency, frequency $\mathrm{x}$ period and intensity $\mathrm{x}$ frequency $\mathrm{x}$ period ( $\mathrm{P}>0.05$ ). The 100\%-LI pastures had a higher HAR during the entire experimental period (29 and 36 $\mathrm{kg} / \mathrm{ha}$ to 95 and 100\%-LI, respectively). There was no grazing intensity effect on HAR, except for the summer 2007 period (January to March) when pastures grazed to $10 \mathrm{~cm}$ had a higher HAR (59 kg/ha) than those grazed to $5 \mathrm{~cm}$ (45 kg/ha; Table 1). Korte et al. (1984) reported that in mixed perennial ryegrass and white clover pastures, HAR was initially high in lenient grazings, but decreased in subsequent grazing cycles.

Table 1 Mean daily herbage accumulation rate (HAR) in Signalgrass pastures managed at different grazing intensity treatments ( 5 and $10 \mathrm{~cm}$ of post-graze sward height) in different periods of year

\begin{tabular}{cccccc}
\hline \multirow{2}{*}{ Intensity } & \multicolumn{5}{c}{ Period } \\
\cline { 2 - 6 } & Jan-Mar 2008 & Apr-Jun 2008 & Jul-Sep 2008 & Oct-Dec 2008 & Jan-Apr 2009 \\
\cline { 2 - 6 } & \multicolumn{5}{c}{ kg DM/ha } \\
\hline \multirow{2}{*}{$5 \mathrm{~cm}$} & $45,3^{\mathrm{B}}$ & 18,0 & 15,3 & 26,9 & 49,6 \\
$10 \mathrm{~cm}$ & $59,3^{\mathrm{A}}$ & 21,5 & 13,8 & 25,5 & 46,2 \\
s.e. & & & $\pm 1,78$ & &
\end{tabular}

LSmeans followed by different superscript letters in columns differ at $\mathrm{P}<0.05$; s.e. $=$ standard error.

Total leaf yield increased when regrowth was extended to reach $100 \%$ ( $\mathrm{P}<0.05$; Table 2), but stem plus dead material increased as well (4877 vs. $7155 \mathrm{~kg} / \mathrm{ha}$ to 95 and 100\%-LI, respectively). In the Tanzania guineagrass (Panicum maximum Jacq. cv. Tanzania-1) pastures, a large increase in stem and dead material in 
pastures managed at 100\% sward LI has been reported (Barbosa et al., 2007). Total leaf yield also increased in pastures grazed to $5 \mathrm{~cm}(\mathrm{P}<0.05)$. However, for the other plant part components, the intensity effect was lower, and it was only noticed in the $100 \%$ LI treatment, where dead material yield was higher for the $10 \mathrm{~cm}$ treatment $(\mathrm{P}<0.05)$. The higher grazing intensity (shorter stubble) used in this study did not seem to cause reduction in forage yield potential. In fact, the results suggest a slight increase of leaf yield with low quantity of stems and dead material.

Table 2 Plant part components yield in Signalgrass pastures managed at different grazing treatments (five and $10 \mathrm{~cm}$ of sward post-graze height; and $95 \%$ and $100 \%$ of pre-graze sward light interception)

\begin{tabular}{|c|c|c|c|c|c|c|c|c|c|}
\hline \multirow[b]{3}{*}{ Intensity } & \multicolumn{9}{|c|}{ Plant Part Components } \\
\hline & \multicolumn{3}{|c|}{ Leaf } & \multicolumn{3}{|c|}{ Stem } & \multicolumn{3}{|c|}{ Dead } \\
\hline & $95 \%$ & $\begin{array}{c}100 \% \\
\mathrm{~kg} \text { DI }\end{array}$ & Mean & $95 \%$ & $\begin{array}{l}100 \% \\
\mathrm{~kg} \mathrm{DM}\end{array}$ & Mean & $95 \%$ & $\begin{array}{c}100 \% \\
\mathrm{~kg} \text { DM/ha }\end{array}$ & Mean \\
\hline $5 \mathrm{~cm}$ & 8329 & 8925 & $8627^{\mathrm{A}}$ & 3194 & 3913 & 3554 & $1340^{\mathrm{b}}$ & $2154^{\mathrm{aB}}$ & 1747 \\
\hline $10 \mathrm{~cm}$ & 7531 & 8533 & $8032^{\mathrm{B}}$ & 3415 & 4907 & 4161 & $1805^{\mathrm{b}}$ & $3336^{\mathrm{aA}}$ & 2571 \\
\hline $\begin{array}{c}\text { Mean } \\
\text { s.e. }\end{array}$ & $7930^{\mathrm{b}}$ & $\begin{array}{l}8729^{\mathrm{a}} \\
\pm 469\end{array}$ & & $3305^{b}$ & $\begin{array}{l}4410^{\mathrm{a}} \\
\pm 588\end{array}$ & & 1573 & $\begin{array}{r}2745 \\
\pm 254\end{array}$ & \\
\hline
\end{tabular}

LSmeans followed by different superscripts in columns (capital) and rows (lower case) differ at $\mathrm{P}<0.05$. s.e. $=$ standard error.

\section{Conclusions}

The likely advantages in extending the rest period expressed as increased HAR were counterbalanced by the increased proportion of stem and dead material in the herbage accumulated, decreasing pasture leafiness and probably nutritive value. Despite the initial yield decrease, the $5 \mathrm{~cm}$ stubble height was considered suitable to the management of Signalgrass, increasing grazing efficiency and as a result decreasing forage loss.

\section{Acknowledgments}

The authors wish to thank Fundação de Amparo à Pesquisa do Estado de São Paulo (FAPESP) for funding this research.

\section{References}

Barbosa, R.A., Nascimento, J.R.D., Euclides, V.P.B., Da Silva, S.C., Zimmer, A.H. \& Torres Jr, R.A.A., 2007. Capim-tanzânia submetido a combinações entre intensidade e freqüência de pastejo. Pesq. Agropec. Bras. 42, 329-340 (in Portuguese, English abstract)

Brougham, R.W., 1956. Effect of intensity of defoliation on regrowth of pasture. Austr. J. Agric. Res. 7, 377-387.

Korte, C.J., Watkin, B.R. \& Harris, W., 1984. Effects of timing and intensity of spring grazings on reproductive development, tillering, and herbage production of perennial ryegrass dominant pasture. N. Z. J. Agric. Res. 27, 135-149.

Marcelino, K.R.A., Nascimento JR, D., Da Silva, S.C., Euclides, V.P.B. \& Fonsece, D.M., 2006. Características morfogênicas e estruturais e produção de forragem do capim marandu submetido a intensidades e freqüências de desfolhação. Rev. Bras. Zootec., 35, 2243-2252 (in Portuguese, English abstract) 